Sains Malaysiana 50(1)(2021): 93-99

http://dx.doi.org/10.17576/jsm-2021-5001-10

\title{
Oocyte Differentiation and Reproductive Health of Solitary Tunicate (Styela plicata) from Eastern Coast of Thailand
}

(Pembezaan Oosit dan Kesihatan Pembiakan Tunikat Bersendirian (Styela plicata) dari Pantai Timur Thailand)

Senarat, S., Kettratad, J., Boonyoung, P., Jiraungkoorskul, W., Kato, F., Mongkolchaichana, E., KAneKo, G. \& PoOlprasert, P.*

\begin{abstract}
Histopathological examination is a widely acknowledged technique to assess the reproductive health of aquatic organisms, but it has never been applied to the tunicate Styela plicata, a potential indicator species of water quality. In this study, we examined the oocyte differentiation of $\mathrm{S}$. plicata obtained from the eastern coast of the Gulf of Thailand in order to provide basic information for future assessment of its reproductive health. The mature gonad of $\mathrm{S}$. plicata comprised several ovo-testicular convoluted tubes, in which each tube was divided into apical and terminal portions. The ovarian tissue is located in the apical part of the tunicate body and contained oocytes of various differentiation stages (asynchronous development type) consisting of the four phases namely oogonial proliferation phase, primary growth phase, secondary growth phase (secondary growth and full-growth stages), and post-ovulatory phase. Changes in the morphology of oocytes and follicular cells were described for each differentiation stage. In addition, we unexpectedly observed a high prevalence of atretic follicles (24.5\%), which might indicate the oocyte damage by environmental stresses. These findings would be useful for future assessment of reproductive histology of S. plicata and other tunicate species from environmental perspectives.
\end{abstract}

Keywords: Ascidian; histology; reproduction; Styela plicata; Thailand

ABSTRAK

Pemeriksaan histopatologi adalah teknik yang telah diakui secara meluas untuk menilai kesihatan reproduktif organisma akuatik, namun teknik ini tidak pernah digunakan untuk mengenal pasti Styela plicata iaitu sejenis spesies yang berpotensi untuk menjadi penunjuk kualiti air. Dalam kajian ini, kami mengkaji pembezaan oosit S. plicata yang diperoleh dari pantai timur Thailand sebagai maklumat asas bagi penilaian tahap kesihatan reproduktif pada masa hadapan. S. plicata yang matang gonad terdiri daripada beberapa tiub berlingkar ovo-testikular dengan setiap tiub dibahagikan kepada bahagian apeks dan hujung. Tisu ovari terletak di bahagian apeks daripada badan tunikat dan mengandungi oosit daripada pelbagai peringkat pembezaan (jenis pembangunan asingkroni) yang terdiri daripada empat fasa iaitu fasa percambahan oogonial, fasa pertumbuhan primer, fasa pertumbuhan sekunder (pertumbuhan sekunder dan peringkat pertumbuhan penuh) dan fasa pasca ovulasi. Perubahan dalam morfologi oosit dan sel folikel diterangkan untuk setiap tahap pembezaan. Di samping itu, kami secara tidak sengaja telah mencerap prevalensi folikel atretik yang tinggi (24.5\%), yang mungkin menunjukkan kerosakan oosit oleh tekanan daripada alam sekitar. Penemuan ini dapat digunakan untuk penilaian masa akan datang mengenai histologi pembiakan S. plicata dan spesies tunikat yang lain daripada perspektif alam sekitar.

Kata kunci: Askidia; histologi; pembiakan; Styela plicata; Thailand

\section{INTRODUCTION}

Histopathology is a powerful tool for evaluating animal health status and provides early warning of environmental risks (Fatma 2009). This technique has been extensively used to investigate vital changes in many tissues and organs, especially in the reproductive system, the dysfunction of which directly leads to a population decline (Adams 2002; Dietrich \& Krieger 2009; Hinton et al. 2001). In particular, the reproductive system of aquatic organisms is sensitive to environmental changes, thus, many studies have employed histopathology for detecting adverse effects of various compounds in laboratory experiments (Spanò et al. 2004; Tillitt et al. 2010) as well as in field investigations (Johnson et al. 2009). 
The histological assessment achieved earlier success in clarifying the reproductive states of various female fish (Blazer 2002; Tyler \& Sumpter 1996; West 1990) and now is being extended to other aquatic chordates as a means to widely assess environmental impacts on aquatic organisms as a whole.

Tunicates, also known as sea squirts and ascidians, are marine animals belonging to the subphylum Urochordata (phylum Chordata). Tunicates are recognised as free-living organisms inhabiting either in sand or mud, or attached to stones, rocks, and other solid substrates. They are considered as a group of potential indicator species of water quality because they accumulate a high amount of pollutants such as heavy metals through filter-feeding (Bellante et al. 2016). It is known that tunicates are hermaphroditic and oviparous organisms (Ogura \& Sasakura 2013; Satoh 1994), but there is still limited knowledge of histological structure and oocyte differentiation, which is useful for histopathological assessment of environment.

The ascidian Styela plicata (Order Stolifobranchia: Family Styelidae) is a tropical to temperate tunicate species widely distributed along the coast of the Gulf of Thailand. The reproductive histology and gametogenesis of this species have been relatively well-investigated among tunicates (Bawab et al. 2012; Kawamura et al. 2011; Villa \& Patricolo 2000). In the present study, we attempted to further expand the knowledge by describing the oocyte differentiation of $S$. plicata using histochemical techniques. Typically, oocyte differentiation in tunicates takes place in apical region of the gonadal convoluted tube (Cloney 1990; Kessel 1966, 1983; Manni et al. 1993; Reverberi 1971) and is classified into four stages based on the size and histological structures (Manni et al. 1995, 1994). We also reported our unexpected finding of high prevalence of atretic follicles in our samples, which might be indicative of health problem of S. plicata in the ecosystem of the eastern Thailand.

\section{MATERIALS AND Methods}

Styela plicata $(\mathrm{n}=30)$ specimens were collected in May 2015 from three main stations (Chonburi, Rayong, and Chanthaburi provinces) located in the eastern coast of the Gulf of Thailand. All samples were euthanised by a rapid cooling shock and fixed in $4 \%$ paraformaldehyde at $4{ }^{\circ} \mathrm{C}$ followed by assessment of the ovarian structure. The fixed tissues were dehydrated and embedded in paraffin by conventional histochemical techniques. Serial sections of $4 \mu \mathrm{m}$ thick were cut in the sagittal plane. The serial longitudinal and cross sections were then stained with Masson's trichrome (MT), periodic acid-Schiff (PAS) and cresyl violet (CV) (Bancroft \& Gamble 2002; Dietrich \& Krieger 2009). The ovarian structure and oogenesis were observed and photographed with a Nikon TE2000-U microscope. The proportion of penetrated oocytes were calculated from three sections per samples (about 50 cells per section, 10×) and represented as a percent proportions.

\section{RESULTS AND DISCUSSION}

\section{OVERALL HISTOLOGICAL AND HISTOCHEMICAL} OBSERVATIONS OF THE OVARY AND OOGENESIS

Both testicular and ovarian tissues were found in a single S. plicata individual (Figure 1(A)). This is in accordance with the previous observations that this tunicate is hermaphrodite (Ogura \& Sasakura 2013; Satoh 1994). In the MT staining, the strongly stained testicular tissue was separated from ovarian structures by a thin layer of connective tissue. The ovarian tissue was located mainly in the apical portion, whereas the testicular tissue was in the terminal portion. Similar histological characteristics have been reported for several other ascidians (Bawab et al. 2012). Several convoluted ovarian tubules were observed, which were covered by a thin layer of germinal epithelium (Figure 1(B)). The oocyte development patterns were similar throughout the ovary. Oocytes at several different developmental stages were observed in a single individual, indicating that the tunicate specimens analyzed in this study have an asynchronous type of ovary development (Figure 1(C) \& 1(F)). These results suggested that $S$. plicata has a protracted spawning period with multiple spawning (Mukai 1977), as similarly seen in Halocynthia hilgendorfi ritteri (Choi et al. 2004). Based on the histological features, oocyte differentiation stages were classified into four phases including oogonia proliferation phase, primary growth phase, secondary growth phase, and post-ovulatory phase. Follicle cells of each egg were attached to a vesicular structure (follicle stalk; Figure 1(D) \& 1(E)) as reported in botryllid ascidians, Botryllus primigenus, B. schlosseri, Botrylloides violaceus and Bo. leachi (Mukai 1977). The follicle stalk was a simple layer of epithelial cells with a proposed role of supporting the ovulated oocyte before entering the branchial and atrial cavities (Mukai 1977). The finding of atretic follicles was the first for this species as shown in Figure 1(B) \& 1(C).

\section{OOGONIA PROLIFERATION PHASE}

The oogonia proliferation phase is the first phase of oocyte development, in which oogonia are differentiated from primordial germ cells (Mukai \& Watanabe 1976). Being about $3.6 \%$ of all oocytes observed in this study, oogonia had the smallest cell size of about 20 to $25 \mu \mathrm{m}$ in diameter. Oogonia were oval shaped with a single nucleus located near the germinal epithelium (Figure 2(A)) as 
reported in other ascidians (Manni et al. 1994; Sugino et al. 1990). Oogonia were surrounded by pre-follicular cells (Figure 2(A) and 2(B)), which were probably originated from free cells in the hemocoel and differentiated into follicle cells (Mukai \& Watanabe 1976).
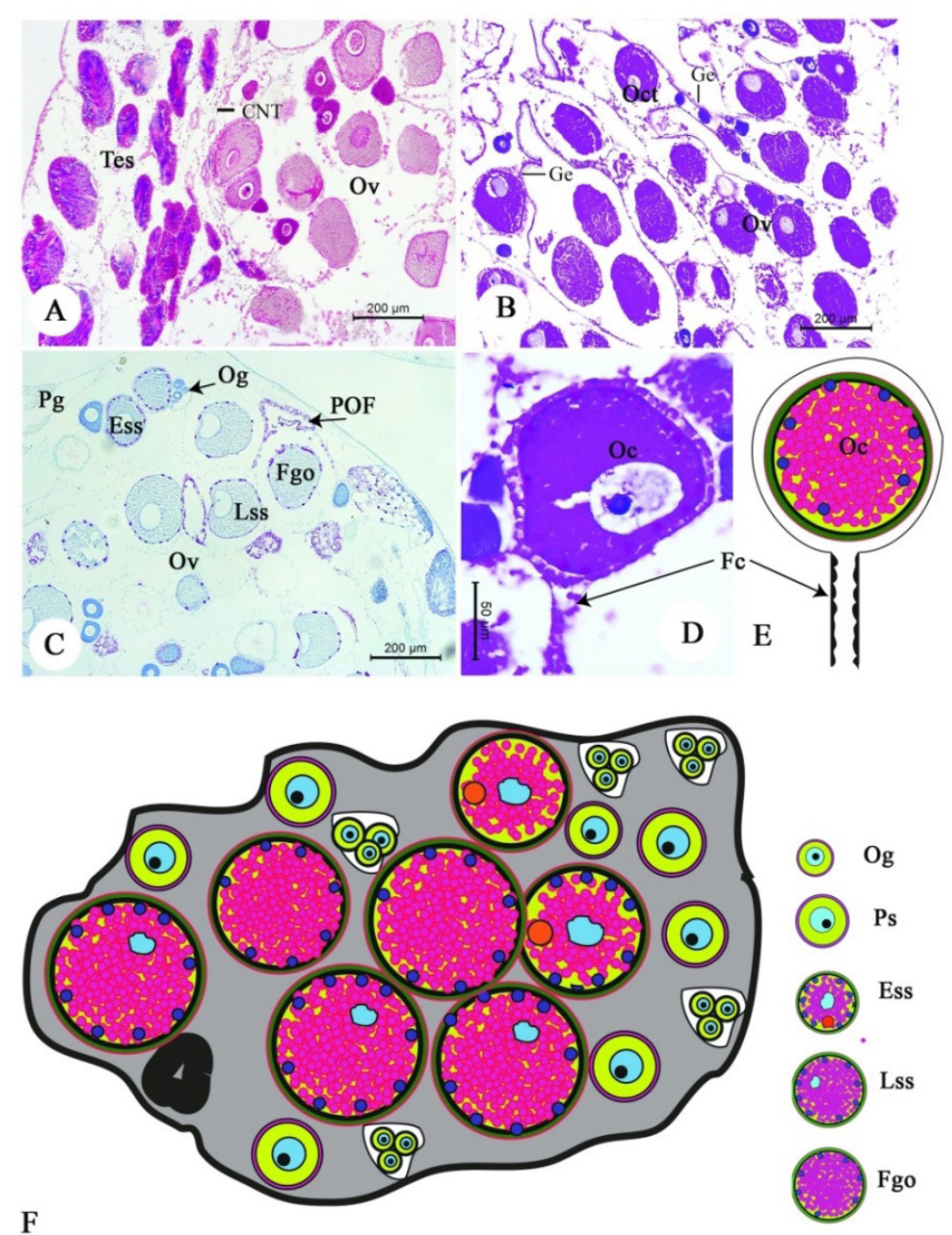

QPOF

FIGURE 1. Light photomicrograph (A-D) and schematic diagrams (E, F) of the ovarian structure of Styela plicata: (A) Ovarian tissue (Ov) mixed with testicular structures (Tes), and (B-F) differentiating oocytes was identified in the ovary: oogomia $(\mathrm{Og})$, oocytes at the primary growth stage (Ps), early secondary growth stage (Ess), late secondary growth stage (Lss), fully-grown oocyte stage (Fgo), and post-ovulatory oocyte (POF)

$\mathrm{CNT}=$ connective tissue, $\mathrm{Fc}=$ Follicular stalk, $\mathrm{Ge}=$ germinal epithelium, $\mathrm{Oc}=$ oocyte, $\mathrm{Oct}=$ ovarian convoluted tubule, Ov = ovarian tissue. Staining methods: (A) Masson's Trichrome (MT) staining, (B, D) Periodic acid schiff (PAS) staining, (C) = cresyl violet (CV) staining

\section{PRIMARY GROWTH PHASE}

Oocytes in the primary growth phase was bigger than those in the oogonia proliferation phase, being about 50 to $70 \mu \mathrm{m}$ in diameter (Figure 2(A) and 2(B)). The proportion of the oocytes in this phase was $8.6 \%$. Each cell was composed of a central nucleus (about $50 \mu \mathrm{m}$ in diameter) containing a single nucleolus of about 5 to $8 \mu \mathrm{m}$. Heterochromatin was observed within the nucleoplasm. A 
strong basophilic staining was observed in the cytoplasm (Figure 2(A), possibly indicating the intense RNA synthesis coupled with ribosome production to support the oocyte development (Wallace \& Selman 1990).

\section{SECONDARY GROWTH PHASE}

The secondary growth phase of oocyte development was further classified into the early secondary growth stage (Ess), late secondary growth stage (Lss) and full-grown oocyte stage (Fgo).

The oocyte size increased to about 100 to $120 \mu \mathrm{m}$ in Ess and oocytes in this stage accounted to $11.2 \%$. The unique characteristic of this stage was a few spherical and acidophilically stained yolk granules observed throughout the ooplasm (Figure 1C). The yolk granules strongly reacted with MT and PAS, indicating the presence of the glycoprotein and mucopolysaccharides (Figure 2(C), 2(E) and 2(F)). The nucleus was eccentric and folded. Test cells of about 5-8 $\mu \mathrm{m}$ were observed in parallel to the vitelline coat (Vc) (Figure 2(C) and 2(D)). Das (1936) classified ascidian test cells based on their shape (large eosinophilic cells, amoeboid cell, small eosinophilous cell, spherical vacuolated cell, and a few granular cells); however, only large eosinophilous cells and amoeboid cells were observed in $S$. plicata under light microscope. Test cells probably function as protein secreting cells to produce the tunic matrix (Endean 1960, 1955; Zaniolo 1981), which may function as a part of the innate immune system (Di Bella et al. 2011). The Vc may be involved in species-specific recognition of gametes (Honegger 1986).

Follicle cells completely surrounded the oocyte in Ess. Follicle cells are composed of two sub-layers, the inner follicle cell layer (IFC) and outer follicle cell layer (OFC) (Figure 2(C) and 2(D)). The OFC with a simple cuboidal epithelium and IFC with an elongated shape were reported in botryllid ascidians, Botryllus primigenus, B. schlosseri, Botrylloides violaceus, and Bo. leachi (Mukai et al. 1987). Oocytes in the secondary, but not the primary, growth phase were surrounded by the OFC. This difference is likely correlated to yolk accumulation during oocyte development since previous works have also demonstrated correlation of flat OFC with few small yolk granules in the oocyte (Manni et al. 1994, 1993; Mukai 1977; Sabbadin et al. 1992; Zaniolo et al. 1987). Indeed, under the ultrastructural analysis, high development of rough endoplasmic reticulum (RER) cisterns, Golgi stacks and dense granules have been observed in the OFC. These features suggest that OFC is composed of protein-secreting cells that support the production/synthesis of the yolk granule in ascidian (Anderson \& Albertini 1976; Manni et al. 1994, 1993). The IFC has been known to contain RER vesicles and fibrillar materials. IFC may play a role in controlling ovulation and embryogenesis (Mukai et al. 1987).
Oocytes in the late secondary growth stage (Lss) were about $150 \mu \mathrm{m}$ in diameter as in the case of oocytes in the Ess. However, Lss oocytes were different from those in Ess in two characteristics, including more yolk granule formations and the Balbiani's body (Figure 2(G)). An oval, non-homogeneous structure observed near the nucleus membrane was likely the Balbiani's body, as reported in some fish (Mayer et al. 1988; Wallace \& Selmann 1981). Balbiani's body consists of organelles including mitochondria and endoplasmic reticulum, and is also rich in nucleic acids (Hamaguchi 1993) and proteins (Wallace \& Selmann 1981). The amoeboid cells were also observed (Figure 2(G)). The proportion of oocytes in this stage was $22.1 \%$.

The Fgo oocytes had a diameter of $170 \mu \mathrm{m}$ and accounted for $25 \%$ of all oocytes examined in this study. Nuclei had an irregular shape and migrated to the animal pole (Figure $2(\mathrm{G}) \& 2(\mathrm{H})$ ). This phenomenon is called the germinal vesicle migration $(\mathrm{GVM})$, which is generally observed during the first meiotic cell division. The follicle layer became flat. No cells showed the germinal vesicle breakdown (GVBD) (Figure 2(I) \& 2(J)).

\section{POST-OVULATORY PHASE}

Post-ovulatory oocytes, also called convoluted postovulatory follicles (POF) and ruptured empty oocytes, accounted for $5 \%$ of all oocytes. Follicle cells had an irregular shape (Figure 2(D) \& 2(K)). These features suggest that our $S$. plicata specimens were in the spawning season, although this assumption requires further studies. Previous reproductive cycle observations have shown some tunicate species such as H. hilgendorfi ritteri (Choi et al. 2004) and Polycarpa cryptocarpa kroboja (Chen \& Dai 1998) to be generally multiple spawners, where spawning are controlled by several factors especially the lunar phase and temperature (Choi et al. 2004).

\section{ATRETIC OOCYTES}

Many oocytes in the secondary growth phase showed degenerative features associated with irregular cell shapes, and therefore considered to be atretic oocytes (24.5\% of oocyte proportion, Figure 2(L)). Disorganisation of the nucleus was often observed together with pyknotic nuclei and karyolysis of follicle cells. It may be possible that heavy metals $(\mathrm{Hg}, \mathrm{Cd}, \mathrm{Pb}, \mathrm{Zn}, \mathrm{Cu}, \mathrm{Ni}$, $\mathrm{Fe}$, and $\mathrm{Mn}$ ) detected along the eastern coast of the Gulf of Thailand (Thongra-ar et al. 2008) resulted in the high prevalence of atretic oocytes. However, current state of heavy metal pollution at the site remains unknown. Indeed, follicular atresia can be a consequence of normal apoptotic process that happens in most animals (Cloney 1990). More evidence is required to conclude that atretic follicles are related to heavy metal pollution. 


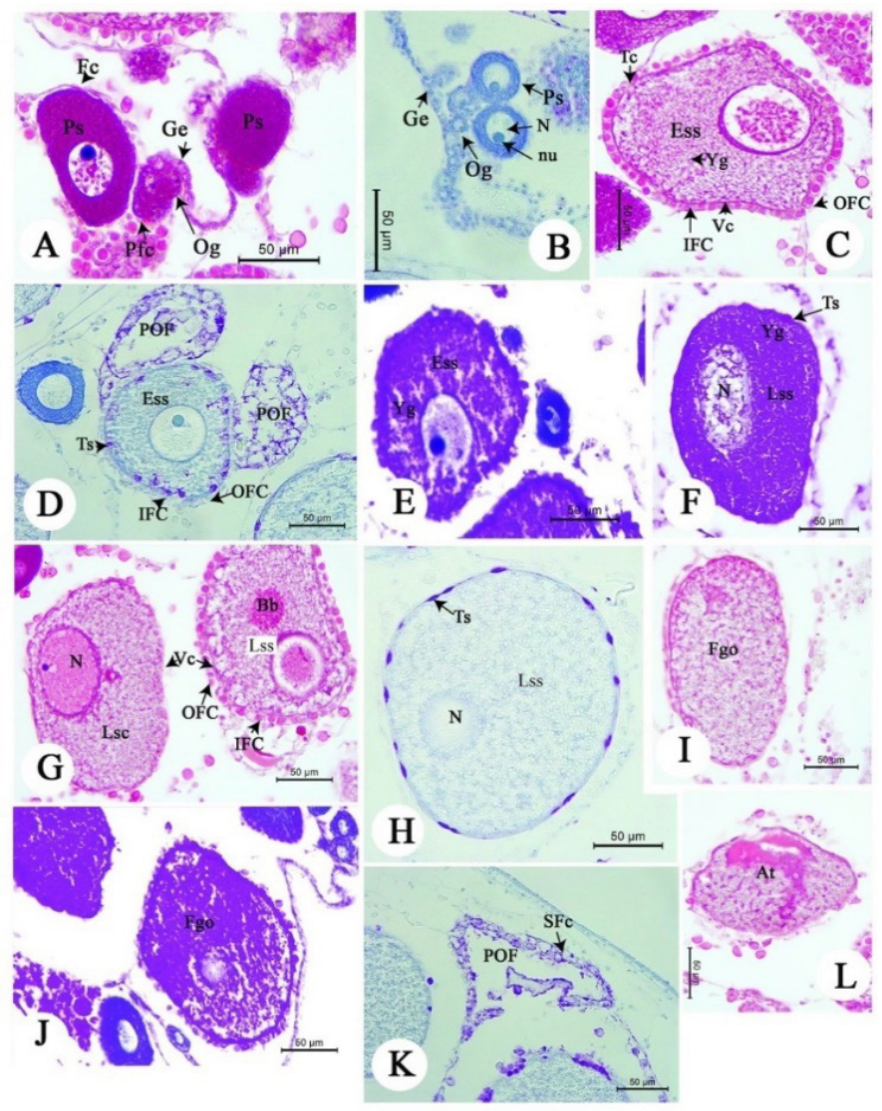

FIGURE 2. Detailed Light photomicrograph of the oogenesis and histological alterations in Styela plicata: (A-B) Oogomia $(\mathrm{Og})$ and primary growth phase (Pp), (C-E) early secondary growth stage (Ess), (F-H) late secondary growth stage, (I-J) full-grown oocyte stage (Fgo),

(K) post-ovulatory oocyte (POF), and (L) atretic oocyte (At)

Abbreviations: $\mathrm{Bb}=$ Balbiani's body, $\mathrm{Fc}=$ Follicular stalk, $\mathrm{Ge}=$ germinal epithelium, $\mathrm{IFC}=$ inner follicle cell, $\mathrm{N}=$ nucleus, $\mathrm{nu}=$ nucleolus, $\mathrm{OFC}=$ outer follicle cell, $\mathrm{Pfc}=$ pre-follicular cell, $\mathrm{SFc}=$ stratified follicle cell layer, $\mathrm{Tc}=$ test cell, $\mathrm{Vc}=$ vitelline coat, $\mathrm{Yg}=$ yolk granules. Staining methods: (A, C, G, I, L) Masson's Trichrome (MT), (B, D, H, K) cresyl violet (CV), (E, F, J) Periodic acid schiff (PAS)

\section{CONCLUSION}

In this study, we described the oocyte differentiation process of a tunicate $S$. plicata, dividing it into four phases. We also observed a high prevalence of atretic follicles, which may be related to the environmental problem in the eastern coast of the Gulf of Thailand. Hopefully, more comprehensive environmental quality of this area could be enhanced.

\section{ACKNOWLEDGEMENTS}

Our appreciation is extended to the Division of Health and Applied Science, Faculty of Science, Prince of Songkla University for practical support.

\section{REFERENCES}

Adams, S.M. 2002. Biological indicators of aquatic ecosystem stress. American Fisheries Society 3: 104-112.

Anderson, E. \& Albertini, D.F. 1976. Gap junctions between the oocyte and companion follicle cells in the mammalian ovary. Journal of Cell Biology 71: 680-686.

Bancroft, J.D. \& Gamble, M. 2002. Theory and Practice of Histological Techniques. London: Churchill Livingstone.

Bawab, F.A.E., Michael, M.I.M., Khalil, S.H. \& Saad, G.A. 2012. Studies on the reproductive and nervous systems of the protochordate Styela plicata (Lesueur, 1823) to correlate the nervous activity on reproduction. The Egyptian Journal of Aquatic Research 38: 125-145. 
Bellante, A., Piazzese, D., Cataldo, S., Parisi, M.G. \& Cammarata, M. 2016. Evaluation and comparison of trace metals accumulation indifferent tissues of potential bioindicator organisms: Macrobenthic filter feeders Styela plicata, Sabella spallanzanii and Mytilus galloprovincialis. Environmental Toxicology and Chemistry 35(12): $3062-$ 3070.

Blazer, V.S. 2002. Histopathological assessment of gonadal tissue in wild fishes. Fish Physiology and Biochemistry 26: 85-101.

Chen, Y.T. \& Dai, C.F. 1998. Sexual reproduction of the ascidian Polycarpa cryptocarpa kroboja from the northern coast of Taiwan. Acta Oceanogr Taiwan 37: 201-210.

Choi, Y., Lee, C., Rho, S. \& Lee, Y. 2004. Reproductive cycle and spawning rhythm of the ascidian, Halocynthia hilgendorfi ritteri. Korean Journal of Biological Science 8: 33-40.

Cloney, R.A. 1990. Reproductive Biology of Invertebrates. New Delhi: Oxford \& IBH Publishing.

Das, B.M. 1936. On the structure and function of the ascidian test. Journal of Morphology 69: 589-601.

Di Bella, M.A., Fedders, H., De Leo, G. \& Leippe, M. 2011. Localization of antimicrobial peptides in the tunic of Ciona intestinalis (Ascidiacea, Tunicata) and their involvement in local inflammatory-like reactions. Results in Immunology 1(1): 70-75.

Dietrich, D.R. \& Krieger, H.O. 2009. Histological Analysis of Endocrine Disruptive Effects in Small Laboratory Fish. New Jersey: John Wiley \& Sons.

Endean, R. 1960. The blood cells of the ascidian, Phallrrsia ttzattlmillafa. Journal of Microscopical Science 101: 177197.

Endean, R. 1955. Studies on the blood and test of some Australian ascidians. 11. The test of Pyrira sfolonifrra (Heller). Australian Journal of Marine and Freshwater Research 6: 139-156.

Fatma, A.S.M. 2009. Histopathological studies on Tilapia zillii and Solea vulgaris from Lake Qarun, Egypt. World Journal of Fish and Marine Science 1: 29-39.

Hamaguchi, S. 1993. Alterations in the morphology of nuages in spermatogonia of the fish, Oryzias latipes, treated with puromycin and actinomycin D. Reproduction Nutrition Development 33: 137-141.

Hinton, D.E., Segner, H. \& Braunback, T. 2001. Toxic response of liver. In Target Organ Toxicity in Marine and Fresh Water Teleosts, edited by Shlenk, D. \& Benson, W.H. London: CRC Press. pp. 224-268.

Honegger, T.G. 1986. Fertilization in ascidians: Studies on the egg envelop, sperm and gamete interaction in Phallusis mammillata. Developmental Biology 118(1): 118-128.

Johnson, R., Wolf, J. \& Braunbeck, T. 2009. OECD Guidance document for the diagnosis of endocrine-related histopathology of fish gonads. Organisation for Economic Co-operation and Development, France.

Kawamura, K., Tiozzo, S., Manni, L., Sunanaga, T., Burighel, P. \& De Tomaso, A.W. 2011. Germline cell formation and gonad regeneration in solitary and colonial ascidians. Developmental Dynamics 240: 299-308.
Kessel, R.G. 1983. Urochordata-Ascidiacea. In Reproductive Biology of Invertebrates, Vol. 1. edited by Adiyodi, K.G. \& Adiyodi, R.G. New York: Wiley. pp. 655-734.

Kessel, R.G. 1966. Ultrastructure and relationships of ooplasmic components in tunicates. Acta Embryologiae et Morphologiae Experimentalis 9: 1-24.

Manni, L., Zaniolo, G. \& Burighel, P. 1995. Oogenesis and oocyte envelope differentiation in the viviparous ascidian Botrylloides violaceus. Invertebrate Reproduction and Development 27: 167-180.

Manni, L., Zaniolo, G. \& Burighel, P. 1994. An unusual membrane system in the oocyte of the ascidian Botryllus schlosseri. Tissue Cell 26: 212-222.

Manni, L., Zaniolo, G. \& Burighel, P. 1993. Ultrastructural study of oogenesis in the compound ascidian Botryllus schlosseri (Tunicata). Acta Zoologica (Stockh) 75: 101-113.

Mayer, I., Shackley, S.E. \& Rylan, J.S. 1988. Aspects of the reproductive biology of the bass, Dicentrarchus labrax L. A histological and histochemical study of oocyte development. Journal of Fish Biology 33: 609-622.

Mukai, H. 1977. Comparative studies on the structure of reproductive organs of four botryllid ascidians. Journal of Morphology 152: 363-380.

Mukai, H. \& Watanabe, H. 1976. Studies on the formation of germ cells in a compound ascidian Botryllus primigenus Oka. Journal of Morphology 148: 337-362.

Mukai, H., Saito, Y. \& Watanabe, H. 1987. Viviparous development in Botrylloides (compound ascidians). Journal of Morphology 193: 263-276.

Ogura, Y. \& Sasakura, Y. 2013. Ascidians as excellent models for studying cellular events in the chordate body plan. Biological Bulletin 224: 227-236.

Reverberi, G. 1971. Ascidians. In Experimental Embryology of Marine and Fresh-Water Invertebrates, edited by Reverberi, G. Amsterdam: North-Holland Publishing Co. pp. 507-550.

Sabbadin, A., Burighel, P. \& Zaniolo, G. 1992. Some aspects of reproduction in ascidians. In Selected Symposia and Monographs, edited by Dallai, R. Modena: Mucchi. pp. 251-265.

Satoh, N. 1994. Developmental Biology of Ascidians. New York: Cambridge University Press.

Spanò, L., Tyler, C.R., van Aerle, R., Devos, P., Mandiki, S.N., Silvestre, F., Thomé, J.P. \& Kestemont, P. 2004. Effects of atrazine on sex steroid dynamics, plasma vitellogenin concentration and gonad development in adult goldfish (Carassius auratus). Aquatic Toxicology 66: 369-379.

Sugino, Y.M., Tominaga, A., Takashima, Y. \& Ishikawa, M. 1990. Early oogenesis in the ascidian Ciona savignyi. Invertebrate Reproduction and Development 17: 165-170.

Thongra-ar, W., Musika, C., Wongsudawan, W. \& Munhapol, A. 2008. Heavy metals contamination in sediments along the eastern coast of the gulf of Thailand. Environment Asia 1: 37-45.

Tillitt, D.E., Papoulias, D.M., Whyte, J.J. \& Richter, C.A. 2010. Atrazine reduces reproduction in fathead minnow (Pimephales promelas). Aquatic Toxicology 99: 149-159. 
Tyler, C.R. \& Sumpter, J.P. 1996. Oocyte growth and development in teleosts. Reviews in Fish Biology and Fisheries 6: 287-318.

Villa, L. \& Patricolo, E. 2000. The follicle cells of Styela plicata (Ascidiacea, Tunicata): A SEM study. Zoological Science 17: 1115-1121.

Wallace, R.A. \& Selman, K. 1990. Ultrastructural aspects of oogenesis and oocyte growth in fish and amphibians. Journal of Electron Microscopy Technique 16: 175-201.

Wallace, R.A. \& Selman, K. 1981. Cellular and dynamic aspects of oocyte growth in teleost. American Zoologist 21: 325-343.

West, G. 1990. Methods of assessing ovarian development in fishes: A review. Journal of Marine and Freshwater Research 41: 199-222.

Zaniolo, G. 1981. Histology of the ascidian Botryllus schlosseritunic: In particular, the test cells. Bolletino di Zoologia 48: 169-178.

Zaniolo, G., Burighel, P. \& Martinucci, G.B. 1987. Ovulation and placentation in Botryllus schlosseri (Ascidiacea): An ultrastructural study. Canadian Journal of Zoology 65: 1181-1190.

Senarat, S.

Department of Marine Science and Environment

Faculty of Science and Fisheries Technology

Rajamangala University of Technology Srivijaya, Trang Campus

Sikao, Trang, 92150

Thailand

Kettratad, J.

Department of Marine Science

Faculty of Science

Chulalongkorn University

Bangkok, 10330

Thailand

Boonyoung, $\mathrm{P}$.

Division of Health and Applied Science, Faculty of Science

Prince of Songkla University

Songkhla, 90110

Thailand
Jiraungkoorskul, W.

Department of Pathobiology

Faculty of Science

Mahidol University

Bangkok, 10400

Thailand

Kato, F.

Amakusa Marine Biological Laboratory

Kyushu University

Kumamoto, 863-2507

Japan

Mongkolchaichana, E.

Department of General Education

Faculty of Science and Health Technology

Navamindradhiraj University

Bangkok, 10300

Thailand

Kaneko, G.

School of Arts and Sciences

University of Houston-Victoria

3007 N. Ben Wilson St. Victoria

Texas, 77901

USA

Poolprasert, P.*

Program of Biology

Faculty of Science and Technology

Pibulsongkram Rajabhat University

Phitsanulok, 65000

Thailand

*Corresponding author; email: poolprasert p@psru.ac.th

Received: 1 April 2019

Accepted: 21 June 2020 